\title{
Host Genotype and Hypersensitive Reaction Influence Population Levels of Xanthomonas campestris pv. vitians in Lettuce
}

\author{
Carolee T. Bull, Samantha J. Gebben, Polly H. Goldman, Mark Trent, and Ryan J. Hayes
}

All authors: U.S. Department of Agriculture, Agricultural Research Service, Crop Improvement and Protection Unit, 1636 E. Alisal St., Salinas, CA 93905; and second author: Science and Math Institute, Hartnell College, 411 Central Ave., Salinas, CA 93901. Accepted for publication 25 September 2014.

\begin{abstract}
Bull, C. T., Gebben, S. J., Goldman, P. H., Trent, M., and Hayes, R. J. 2015. Host genotype and hypersensitive reaction influence population levels of Xanthomonas campestris pv. vitians in lettuce. Phytopathology 105:316-324.

Dynamics of population sizes of Xanthomonas campestris pv. vitians inoculated onto or into lettuce leaves were monitored on susceptible and resistant cultivars. In general, population growth was greater for susceptible (Clemente, Salinas 88, Vista Verde) than resistant (Batavia Reine des Glaces, Iceberg, Little Gem) cultivars. When spray-inoculated or infiltrated, population levels of $X$. campestris pv. vitians were consistently significantly lower on Little Gem than on susceptible cultivars, while dif-

lations between bacterial concentration applied and disease severity for all cultivars, but bacterial titer had a significantly greater influence on disease severity in the susceptible cultivars than in Little Gem and an intermediate influence in Iceberg and Batavia Reine des Glaces. Infiltration of $X$. campestris pv. vitians strains into leaves of Little Gem resulted in an incompatible reaction, whereas compatible reactions were observed in all other cultivars. It appears that the differences in the relationship between population dynamics for Little Gem and the other cultivars tested were due to the hypersensitive response in cultivar Little Gem. These findings have implications for disease management and lettuce breeding because $X$. campestris pv. vitians interacts differently with cultivars that differ for resistance mechanisms.
\end{abstract} ferences in the other resistant cultivars were not consistently statistically significant. Populations increased at an intermediate rate on cultivars Iceberg and Batavia Reine des Glaces. There were significant positive corre-
Additional keywords: Lactuca sativa, X. hortorum.
Bacterial leaf spot, caused by Xanthomonas campestris pv. vitians (Brown 1918) Dye 1978, is an important disease of lettuce (Lactuca sativa L.) worldwide. The disease has been reported throughout the United States $(2,6,13,25,31,35,37)$, as well as in Australia $(6,13,16)$, Brazil (6), Canada $(11,40)$, Germany $(6,13)$, Italy $(6,13,30,48)$, Japan $(6,13,42)$, New Zealand (5), Russia (6), Saudi Arabia (1), South Africa (46), South Korea (28), Turkey (34), Venezuela (12), and Zimbabwe (6). The economic impact of the disease in North America and along the Central Coast of California, the largest lettuce-production region in the United States, has increased over the last 20 years $(2,9)$. The pathogen causes small angular leaf spots, which start out water-soaked and can later become brown to black. In severe outbreaks, lesions enlarge and coalesce $(9,13,35,41)$. When the disease occurs, it can result in a reduction in the size of the lettuce head and can increase the potential for postharvest loss, which directly reduces the quality and value of the crop $(2,11)$.

The epidemiology of the pathogen is slowly emerging. The pathogen is reportedly seedborne $(16,37,43)$. However, attempts to isolate the bacterium from commercial seed lots have failed $(2,29,43,48)$. The pathogen can remain viable in plant residue for several months; this infested residue serves as an inoculum source for subsequent crops (2). Likewise, weeds may serve as an

Corresponding author: C. T. Bull; E-mail address: Carolee.Bull@ars.usda.gov

* The $\boldsymbol{e}$-Xtra logo stands for "electronic extra" and indicates that the online version contains two supplemental tables and three supplemental figures.

http://dx.doi.org/10.1094/PHYTO-07-14-0185-R

This article is in the public domain and not copyrightable. It may be freely reprinted with customary crediting of the source. The American Phytopathological Society, 2015. important reservoir for the pathogen either due to survival as a phyllosphere colonist or as a pathogen on some weed species $(2,32,35,41,42)$. However, the host range is likely to be smaller than reported (32).

Chemical control measures may be used to reduce disease in an integrated management program; however, control is variable and prophylactic application of chemicals may not be economical because occurrence of the disease is sporadic $(2,8,11)$. Additionally, several effective copper-based compounds are known to be phytotoxic on lettuce. Consequently, there are no real chemical control options registered. Thus, research has concentrated on identifying host resistance as the primary strategy to manage bacterial leaf spot of lettuce. Some butterhead, cos, crisphead, green and red leaf, Latin, and Batavia types of cultivars or selections have been confirmed as resistant in field and greenhouse evaluations $(9,11,20,27,35)$, and the inheritance of this resistance is being investigated $(18,21,25,27)$. A single dominant gene is responsible for conferring resistance in La Brillante $(18,21)$. The same gene or a closely linked gene is also responsible for resistance in cultivars Little Gem and Pavane (21). Little is known about the inheritance of partial resistance in Iceberg, Salad Crisp, and Batavia Reine des Glaces cultivars, although these have been successfully used to breed new resistant germplasm $(17,19)$.

Although resistant cultivars have been identified, little is known about interactions between $X$. campestris pv. vitians and resistant hosts. This is largely because research on this pathosystem has been conducted with susceptible cultivars or experimental host plants (cultivated crops for which a disease outbreak has not been reported to be caused by $X$. campestris pv. vitians but on which a plant reaction occurs). On susceptible cultivars, $X$. campestris pv. vitians reaches stationary phase or maximum populations of approximately $10^{8} \mathrm{CFU} / \mathrm{cm}^{2}$ or $10^{12} \mathrm{CFU} / \mathrm{g}$ of leaf tissue $(1,32$, 
$35,40)$. There are significant differences in maximum population levels reached and population dynamics of $X$. campestris pv. vitians on experimental host plants and weed species $(1,32,41)$. $X$. campestris pv. vitians appears to cause disease on wild Lactuca spp. (L. serriola and L. biennis), and maximum population levels on these plants are similar to the levels reached on susceptible commercial lettuce (41). The knowledge of population dynamics of $X$. campestris pv. vitians on a resistant cultivar is limited to one report: a resistant cultivar that is no longer available had significantly lower populations of the pathogen than the susceptible cultivars evaluated (35). This indicates that the population dynamics of $X$. campestris pv. vitians on resistant lettuce genotypes may be different than on susceptible genotypes.

The research presented here investigated $X$. campestris pv. vitians colonization of several cultivars that were well-characterized for resistance or susceptibility to $X$. campestris pv. vitians. We hypothesized that the lettuce genotype on which pathogenic bacteria alighted would influence the development of the bacterial population levels on and in leaf tissue and consequently disease development. The influence of host genotype on the overall process of colonization of the leaf was described. The research demonstrated that $X$. campestris pv. vitians colonization differed among cultivars, established that a relationship between bacterial population levels and disease severity was influenced by lettuce genotype, and documented a hypersensitive response (HR)-based resistance in the cultivar Little Gem. Preliminary results from this work have been published $(10,14,15,18)$.

\section{MATERIALS AND METHODS}

Bacterial strains and culture media. A mixture of $X$. campestris pv. vitians strains BS339, BS340 (Xav 98-12), and BS347 from the Salinas Valley $(2,8)$ was used in field experiments. These strains are genetically similar to each other and are members of the X. hortorum (45) group B (36), as are most of the strains causing bacterial leaf spot of lettuce in the Salinas Valley (C. T. Bull and R. J. Hayes, unpublished data). For other experiments, inoculum consisted of BS347 or a spontaneous rifampicinresistant variant of strain BS340 (BS2885). The rifampicinresistant variant BS2885 was selected on nutrient agar (NA; Difco Laboratories, Sparks, MD) amended with $100 \mu \mathrm{g} / \mathrm{ml}$ of rifampicin (47). The rifampicin-resistant variant did not differ from the wild type for generation time in nutrient broth (NB; Difco Laboratories), DNA fragment banding pattern generated by repetitivesequence polymerase chain reaction (rep-PCR), or virulence on the susceptible lettuce cultivar Vista Verde (data not shown). The bacteria were stored at $-80^{\circ} \mathrm{C}$ in a solution of $50 \%$ glycerol and $50 \%$ NB. Bacteria were routinely cultured on NA. All chemicals were purchased from Sigma Corporation (St. Louis, MO) unless otherwise indicated.

Unless otherwise noted, all inocula were prepared by propagating bacteria as lawns on NA for $48 \mathrm{~h}$ at $27^{\circ} \mathrm{C}$. Bacteria were recovered by flooding plates with $0.01 \mathrm{M}$ sterile potassium phos-

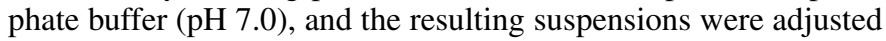
to the desired concentrations spectrophotometrically, using a Shimadzu spectrophotometer model number UV-1601 (Kyoto, Japan). Plate counts of bacterial inoculum indicated that a 0.6 optical density at $600_{\mathrm{nm}}$ was approximately $5 \times 10^{8} \mathrm{CFU} / \mathrm{ml}$ (data not shown).

Influence of bacterial population levels on leaves on disease development. The influence of bacterial titration on disease development was evaluated in greenhouse and field studies on susceptible and resistant cultivars. In the field experiments, the influence of multiple applications was also evaluated.

Greenhouse studies. The influence of bacterial population levels on disease development was assessed in the greenhouse using methods developed for germplasm screening (9). Seeds of three susceptible (Clemente, Salinas 88, Vista Verde) and three resistant (Batavia Reine des Glaces, Iceberg, Little Gem) lettuce cultivars (9) were planted in potting mix (SuperSoil, Rod Mclellan Co., San Mateo, CA) in 2- $\times 2$-cm square cells in $11 \times$ 15 cell flats. Flats were incubated at $10^{\circ} \mathrm{C}$ for 2 days in the dark followed by incubation in the greenhouse. Bacterial suspensions of $X$. campestris pv. vitians BS347 were prepared as described above, adjusted to concentrations of approximately $10^{3}, 10^{5}, 10^{7}$, and $10^{9} \mathrm{CFU} / \mathrm{ml}$ in phosphate buffer, and then verified. The inocula were sprayed using a hand-held spray bottle onto the leaves of 3-week-old plants (each with three fully expanded true leaves) until run-off, with each plant receiving approximately $1 \mathrm{ml}$. Control plants were sprayed with phosphate buffer. Plants were incubated in a greenhouse misting room (at approximately $26^{\circ} \mathrm{C}$ day, $18^{\circ} \mathrm{C}$ night, with ambient light and $\mathrm{RH}$ varying from 80 to $100 \%$ due to mist cycles, with $30 \mathrm{~min}$ of misting followed by $30 \mathrm{~min}$ of nonmisting) for a total of 21 days. From each plant, the single most severely diseased leaf was evaluated for disease severity at 7, 14, and 21 days postinoculation, using a disease severity rating scale modified from Bull et al. (9). Disease incidence for each treatment was also recorded. A rating of 0 was given for plants with no disease; 1 for plants with one to five lesions of $<3 \mathrm{~mm} ; 2$ for plants with distinct lesions $>3 \mathrm{~mm} ; 3$ for plants with coalesced lesions; 4 for plants with coalesced lesions covering $30 \%$ or greater of any leaf; 5 for plants with $50 \%$ or greater of any leaf diseased; and 6 for plants with dead leaves.

The experiment was designed with a split-plot layout, with bacterial population size as the main plot and cultivar as the subplot. Each replication consisted of a row of 11 cells planted to a single cultivar, and there were four replications per treatment. A single plant from each treatment replicate was sampled on each sampling date. The experiment was conducted twice. Disease severity ratings were used to calculate area under the disease progress curve (AUDPC). These AUDPC values were calculated for each bacterial population level. Additionally, the influence of applied bacterial populations on the AUDPC was plotted for each cultivar, and for each replicate an additional value was calculated representing the area under this inoculum titration disease progress curve (AU-ITDPC). The relationship between applied bacterial concentration and AUDPC was compared across all cultivars using the MIXED procedure in SAS (SAS 9.1, SAS Institute, Cary, NC). Data from the two experiments were combined for the analysis; bacterial concentration and cultivar were treated as fixed effects, and experiment was considered a random effect. The effect of cultivar on AU-ITDPC values was also assessed using the MIXED procedure in SAS, and data from the two experiments were similarly combined. Post-hoc pairwise comparisons were made using Student's $t$ test. Since disease severity was measured using an ordinal, rather than a continuous scale, the analyses were done nonparametrically, using the methods of Shah and Madden (38).

Field studies. To understand the impact of pathogen population levels and multiple depositions on disease development under field conditions, three experiments were conducted on the susceptible cultivar Vista Verde (fall 2002, fall 2003, and spring 2004) using previously described methods (9). In the latter two experiments, the resistant cultivar Iceberg was also included. Lettuce was direct-seeded in two rows per 102-cm (40-in.) bed in either early April or late August and thinned 3 to 4 weeks later to $30 \mathrm{~cm}$ between plants. The experiment was designed as a randomized complete block with four replicates. Field plots were $3 \mathrm{~m}$ long and one bed wide, with approximately 20 plants per plot and a minimum of a 0.6-m gap between plots.

For all experiments, three strains of $X$. campestris pv. vitians were grown in individual flasks of NB on a shaker at $200 \mathrm{rpm}$ for $48 \mathrm{~h}$. Cultures were centrifuged for $10 \mathrm{~min}$ at 7,000 rpm (9,000 rcf) to pellet bacteria, and pellets were combined, resuspended in sterile distilled water, centrifuged again, and then resuspended in phosphate buffer. The resultant mixed bacterial suspension was 
serially diluted to approximately $10^{9}, 10^{7}$, and $10^{5} \mathrm{CFU} / \mathrm{ml}$. Bacterial concentrations were confirmed by dilution plating. Approximately $1 \mathrm{ml}$ of inoculum was applied to each plant using a $\mathrm{CO}_{2}$ pressurized hand-held sprayer (model D, R \& D Sprayers, Opelousas, LA) one, two, or three times in one-week intervals beginning one week after thinning ( 28 to 34 days postplanting). To enhance disease development, 5 min of overhead irrigation was applied immediately before bacterial inoculations. All lettuce plantings were grown according to standard commercial practices, which included overhead irrigation applied approximately weekly for the duration of the trial.

Disease incidence and severity were measured on all plants in each plot 1 week before harvest $(93,78$, or 70 days after planting, depending on the experiment). Disease incidence was determined by calculating the proportion of diseased plants in each treatment replicate. Disease severity was evaluated on a per-plant basis using a previously published disease rating scale (8). A rating of 0 was given for plants with no visible symptoms, 1 for plants with one to 10 individual lesions, 2 for plants with more than 10 individual lesions, 3 for plants with small patches (less than $10 \%$ of the leaf affected) of coalesced lesions, 4 for plants with mediumsized patches (10 to $50 \%$ of the leaf affected) of coalesced lesions, and 5 for plants with large patches (greater than $50 \%$ of the leaf affected) of coalesced lesions (see reference 8 for images of each level of disease). Per-plant disease severity values were then averaged across all plants within each treatment replicate. Data were analyzed nonparametrically using the MIXED procedure in SAS (SAS 9.1, SAS Institute) as described above and according to the methods of Shah and Madden (38). In these analyses, bacterial concentration rates and number of applications were both treated as class variables. In addition, Spearman's partial rank-order correlation coefficients $\left(r_{s}\right)$ were calculated (using PROC CORR in SAS) to examine (i) the strength of the relationship between bacterial concentration and disease severity, controlling for the effects of number of bacterial applications and (ii) the strength of the relationship between the number of bacterial applications and disease severity, controlling for the effects of bacterial concentration. In these analyses, the bacterial concentration and number of applications were treated as continuous variables. In both types of analysis, the two cultivars were analyzed separately.

Population dynamics of $X$. campestris pv. vitians on susceptible and resistant cultivars of lettuce. General methods. The following general methods apply to all the experiments described in subsequent subsections. Specifics for individual experiments are provided in the subsections below.

Population dynamics of spray-inoculated $X$. campestris pv. vitians were evaluated on resistant (Batavia Reine des Glaces, Little Gem) and susceptible (Vista Verde, Sniper, Salinas 88, Clemente) lettuce cultivars. Lettuce seeds were planted in flats $(11 \times 31$ cells, $2-\times 2-\mathrm{cm}$ squared cells), with five rows (55 plants) per cultivar per replication and six replications. The cultivars were randomized independently within each block (i.e., each flat). The flats were watered and incubated in a growth chamber at $10^{\circ} \mathrm{C}$ in the dark for two days followed by incubation in the greenhouse at approximately $26^{\circ} \mathrm{C}$ day, $18^{\circ} \mathrm{C}$ night, with ambient light. Four-week-old seedlings were spray-inoculated until runoff with a rifampicinresistant strain $(\mathrm{BS} 2885)$ at a low $\left(10^{4} \mathrm{CFU} / \mathrm{ml}\right)$ or high $\left(10^{10}\right.$ $\mathrm{CFU} / \mathrm{ml}$ ) concentration, allowed to dry for $1 \mathrm{~h}$, and then incubated in a greenhouse misting room (with RH varying from 80 to $100 \%$ as described previously) for the remainder of the experiment.

For all experiments, leaf samples (selected as described in each subsection below) from single leaves of single plants were excised aseptically using a $0.8-\mathrm{cm}^{2}$ cork borer. Tissue was thoroughly macerated in $300 \mu \mathrm{l}$ of sterile phosphate buffer in a microfuge tube using a wooden dowel. The resulting suspensions and serial dilutions were streaked onto NA amended with rifampicin, and population levels were estimated from the colonies that grew 3 to 5 days after incubation at $27^{\circ} \mathrm{C}$. Unless otherwise noted, in samples from which no colonies grew, those zero values were replaced with the limit of detection ( $46 \mathrm{CFU}$ ) minus $1 \mathrm{CFU}$.

Population dynamics of bacteria in symptomatic or asymptomatic tissue. The general methods described above were used for planting, inoculation, and sampling. Vista Verde (susceptible) and Little Gem (resistant) plants were inoculated with high bacterial concentrations and then were evaluated 3 and either 4 or 6 weeks after inoculation. For the evaluation, bacterial populations in symptomatic tissue were compared with the levels in asymptomatic tissue. The largest lesion from an inoculated leaf was excised aseptically, using a $0.8-\mathrm{cm}^{2}$ cork borer, from tissue between major veins. Tissue devoid of visible symptoms was selected from the same leaf and sampled using identical methods. The sampled leaves were evaluated for disease severity using the rating scale described previously for greenhouse experiments. The experiment was conducted twice, and data from the two experiments were pooled for analyses.

Bacterial population data were log-transformed and compared using a mixed-model ANOVA design in JMP (v10.0, SAS Institute). Lesion status (present/absent) was nested within cultivar, with both variables treated as fixed effects. Experiment was treated as a random effect. Pairwise differences between the treatment means were determined using Student's $t$ test. To determine whether a relationship existed between disease severity rating and bacterial population sizes, the two measures were compared via ANOVA using data solely from the samples that were symptomatic. Bacterial population size was treated as the independent variable and disease severity rating and cultivar as the dependent variables.

Population dynamics of bacteria applied at low or high levels as foliar spray inoculations. The population dynamics of the pathogen deposited at low or high concentrations of inoculum were evaluated separately in replicated experiments. The general methods described above were used for planting, inoculation, and sampling. Six cultivars were evaluated: Vista Verde, Clemente, Sniper, and Salinas 88 (susceptible cultivars) and Little Gem and Batavia Reine des Glaces (resistant). For experiments at the low inoculum level, samples were taken from the upper quadrant of one of the first three fully expanded leaves, regardless of disease symptom status. In the subsequent experiments at the high inoculum level, samples were taken from the most severe lesion once symptoms appeared. Population levels were measured at the time of inoculation and at approximately weekly intervals for up to 33 days. The area under the population curve (AUPC) was calculated for each replicate using the population data $\left(\mathrm{CFU} / \mathrm{cm}^{2}\right)$ from each date and standard methods for calculating the AUPC (26). For these calculations, missing values for individual sampling dates were not estimated; instead, the time intervals were adjusted to reflect the data available. The AUPC data were then log-transformed and compared in JMP using a mixed-model ANOVA, with experiment treated as a random effect. Pairwise differences among cultivars were assessed using Tukey's honest significant difference (HSD) test.

Population dynamics of $X$. campestris pv. vitians and plant reaction to infiltration of the pathogen into lettuce leaf tissue. Bacterial suspensions of the rifampicin-resistant $X$. campestris $\mathrm{pv}$. vitians strain BS2885 were prepared as described previously. The adaxial surfaces of leaves of 5-week-old resistant (Little Gem, Batavia Reine des Glaces) and susceptible (Vista Verde, Clemente, Salinas 88) lettuce plants were marked with a permanent marker before inoculation. Using a $1-\mathrm{ml}$ syringe without a needle, bacteria were infiltrated through stomata on the abaxial surface of leaves until the intercellular spaces of the mesophyll were watersoaked within restraint of the major leaf veins. For each bacterial treatment, bacteria were infiltrated into six leaves (replications) for each cultivar at two sites per leaf with the bacterial suspension, and at a third site they were infiltrated with phosphate buffer 
as a control. One leaf from each cultivar was randomly selected for analysis at each sampling time, with one infiltration site used to evaluate population dynamics of the pathogen and the second infiltration site used to monitor the plant reaction. Inoculated plants were arranged on a growth-room bench at $20^{\circ} \mathrm{C}$ and a $16-\mathrm{h}$ day length in a completely randomized design.

The interaction (compatible or incompatible) between the plant and the pathogen was recorded, and bacterial population levels within the infiltration site were evaluated. Samples were taken from within the infiltrated area at $0,24,72$, and $168 \mathrm{~h}$ postinoculation (hpi) to quantify bacterial population levels, and observations were made at $0,24,48,72$, and 96 hpi to determine plant reaction to the challenge from the pathogen. Bacterial population levels were estimated from tissues excised from within the marked region of the leaves using the methods described in the previous section. The experiment was conducted twice.

To evaluate growth of bacterial populations, AUPC values were calculated. Cultivar was treated as a fixed effect and experiment as a random effect. Data were log-transformed and then further square-root-transformed to meet the model assumptions of normality and homogeneity of variances and then were analyzed using ANOVA and Tukey's HSD, as described in the previous section. Population levels are presented as the log-transformed means for each cultivar at each sampling time.

The interactions between the plants and the pathogen were determined incompatible if the HR occurred, with cell death initially observed visually by $24 \mathrm{hpi}$ and development of a tan to brown color with a dry, papery texture by 48 hpi (Supplemental Figure 1). The interaction was determined to be compatible if the visual lesion development was delayed until at least 48 hpi and was characterized by the development of dark brown to black color that appeared water soaked. Visual observations were verified by fluorescent microscopy at 24,48 , and 72 hpi. Cross sections of the infiltrated area were observed for dead plant cells using a $4 \times$ objective on an Olympus BX60 microscope equipped for epifluorescence with an Olympus model BH2-RGL-T3 100-W high-pressure mercury light source (Olympus America Inc.,
Center Valley, PA) and a Chroma Technology Corp. (Bellows Falls, VT) $11003 \mathrm{v} 2$ blue/violet filter set that included an excitation filter at $425 \mathrm{~nm}$, a dichroic beam splitter at $450 \mathrm{~nm}$, and an emission filter at $475 \mathrm{~nm}$ mounted in an Olympus U-MF2 filter cube. Under these conditions, live plant cells appear red while dead plant cells appear bright yellow to yellow-green. Incompatible interactions were confirmed if dead plant cells were observed at $24 \mathrm{hpi}$, and compatible interactions were confirmed if dead plant cells could not be consistently observed until 72 hpi (Supplemental Figure 2).

\section{RESULTS}

Influence of bacterial population levels on disease development. Greenhouse studies. In Little Gem, damage due to $X$. campestris pv. vitians was the result of an HR caused by localized cell death directly at the site of natural openings in the leaves (hydathodes), whereas in all the other cultivars the lesions were water-soaked and spreading (Supplemental Figure 3). In disease assessments, damage was evaluated regardless of whether it was the result of an HR or disease.

Population levels deposited on leaf surfaces influenced disease development in both susceptible and resistant cultivars, but increasing concentrations of the applied pathogen had less impact on disease severity on the resistant cultivar Little Gem than on other cultivars tested. The increase in AUDPC values over the range of bacterial concentrations was significantly lower for Little Gem in comparison with the susceptible cultivars Vista Verde, Clemente, and Salinas 88 as measured by the AU-ITDPC (Fig. 1). Likewise, the AUDPCs were significantly lower at specific applied populations for Little Gem as compared to Vista Verde at $\log 7$ and all the susceptible cultivars at Log 9 (Supplemental Table 1). The increases in disease severity (data not shown) and AUDPC values over the AU-ITDPC for the resistant cultivars Batavia Reine des Glaces and Iceberg were intermediate between those of the susceptible cultivars and Little Gem and were not statistically different from either.

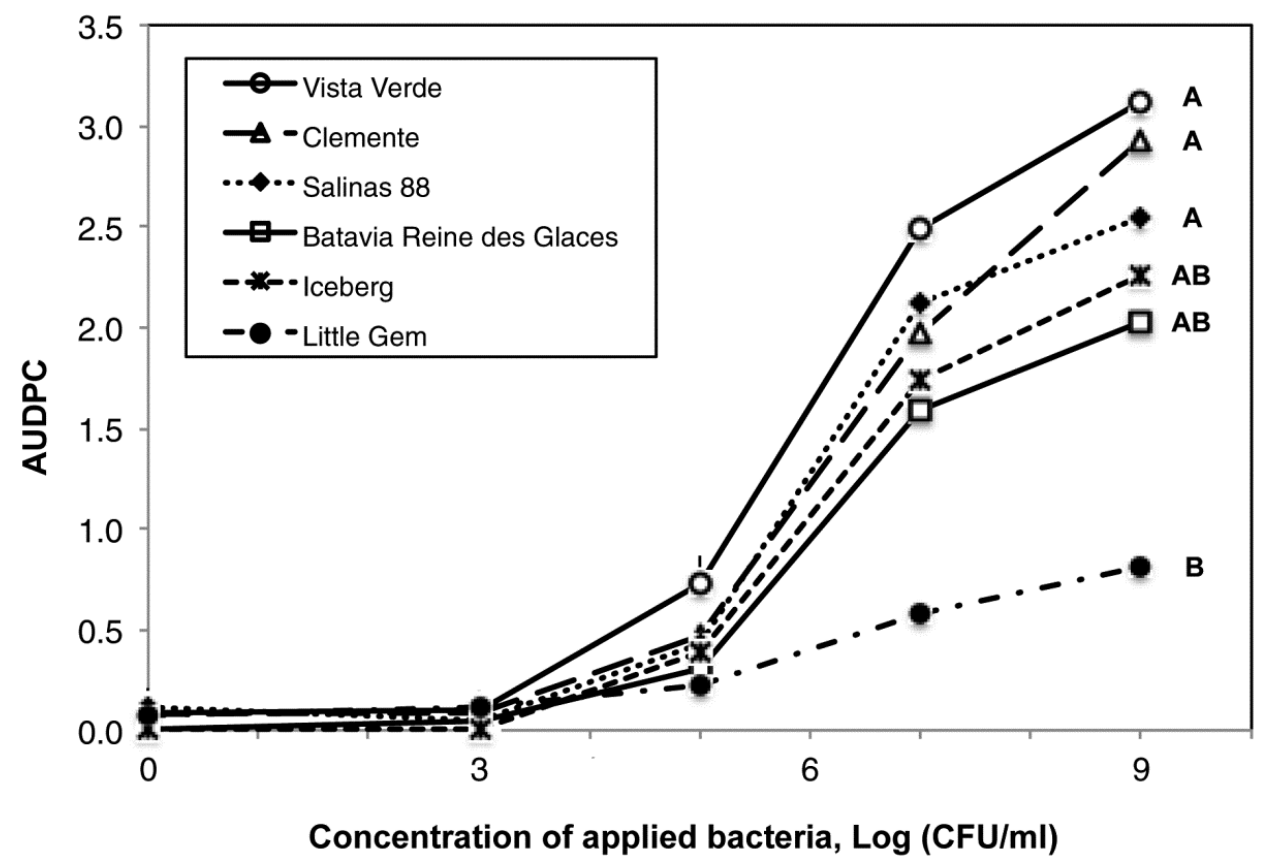

Fig. 1. Effect of concentration of applied Xanthomonas campestris pv. vitians on disease severity in greenhouse-grown lettuce. Approximately $1 \mathrm{ml}$ of bacterial suspensions adjusted to the designated concentrations was applied by spray-inoculation to 5-week-old susceptible (Vista Verde, Salinas 88, Clemente) and resistant (Batavia Reine des Glaces, Iceberg, Little Gem) lettuce plants. Plants were incubated at 100\% RH in a greenhouse. Disease severity was evaluated using a 0 to 6 rating scale. Each point represents the mean area under the disease progress curve (AUDPC) of three plants in each of two pooled experiments. Pairwise comparisons between cultivars of the area under these curves (the AU-ITDPC values) was done using PROC MIXED in SAS following rank transformation of the data. Significant $(P<0.05$, Student's $t$ test $)$ pairwise differences in these values are indicated with different letters at the endpoint of each curve on the figure. 
Field studies. Disease severity was positively correlated with the concentration of bacteria applied to both the susceptible cultivar Vista Verde (Fig. 2A, $r_{s}=0.714, P<0.0001$; Supplemental Table 2) and the resistant cultivar Iceberg (Fig. 2B, $r_{s}=$ $0.592, P<0.0001)$. Disease incidence and concentration of bacteria applied were similarly correlated in Iceberg $\left(r_{\mathrm{s}}=0.558, P<\right.$ 0.0001 , data not shown). Analysis of disease incidence data in Vista Verde was complicated by the fact that it had $100 \%$ disease incidence across all treatments in all but one experiment. In this one experiment, a significant positive correlation was found between applied bacterial concentration and disease incidence $\left(r_{s}=0.480, P<0.0001\right.$, data not shown). Multiple applications of the same concentration of bacteria significantly increased disease severity in the resistant cultivar $\left(r_{s}=0.266, P=0.009\right)$ (Fig. 2B) but had no significant impact on disease incidence in this cultivar $\left(r_{s}=0.142, P=0.171\right)$ and no significant impact on either measure in the susceptible cultivar (incidence: $r_{s}=0.036, P=$ 0.667; severity: $r_{s}=0.101, P=0.232$ ) (Fig. $2 \mathrm{~A}$ ).

Population dynamics of $X$. campestris pv. vitians on susceptible and resistant cultivars of lettuce. In symptomatic or asymptomatic tissue. Bacterial population levels were significantly higher in Vista Verde than in Little Gem in leaf tissue samples both with $(P<0.0001)$ or without $(P=0.035)$ lesions (Fig. 3). Within each cultivar, population levels of bacteria in symptomatic tissue were significantly higher than those in samples of asymptomatic tissue.

In both experiments, the populations tended to increase over time in both symptomatic and asymptomatic Vista Verde tissues and to decrease over time in Little Gem symptomatic tissues (data not shown). However, differences in bacterial populations in
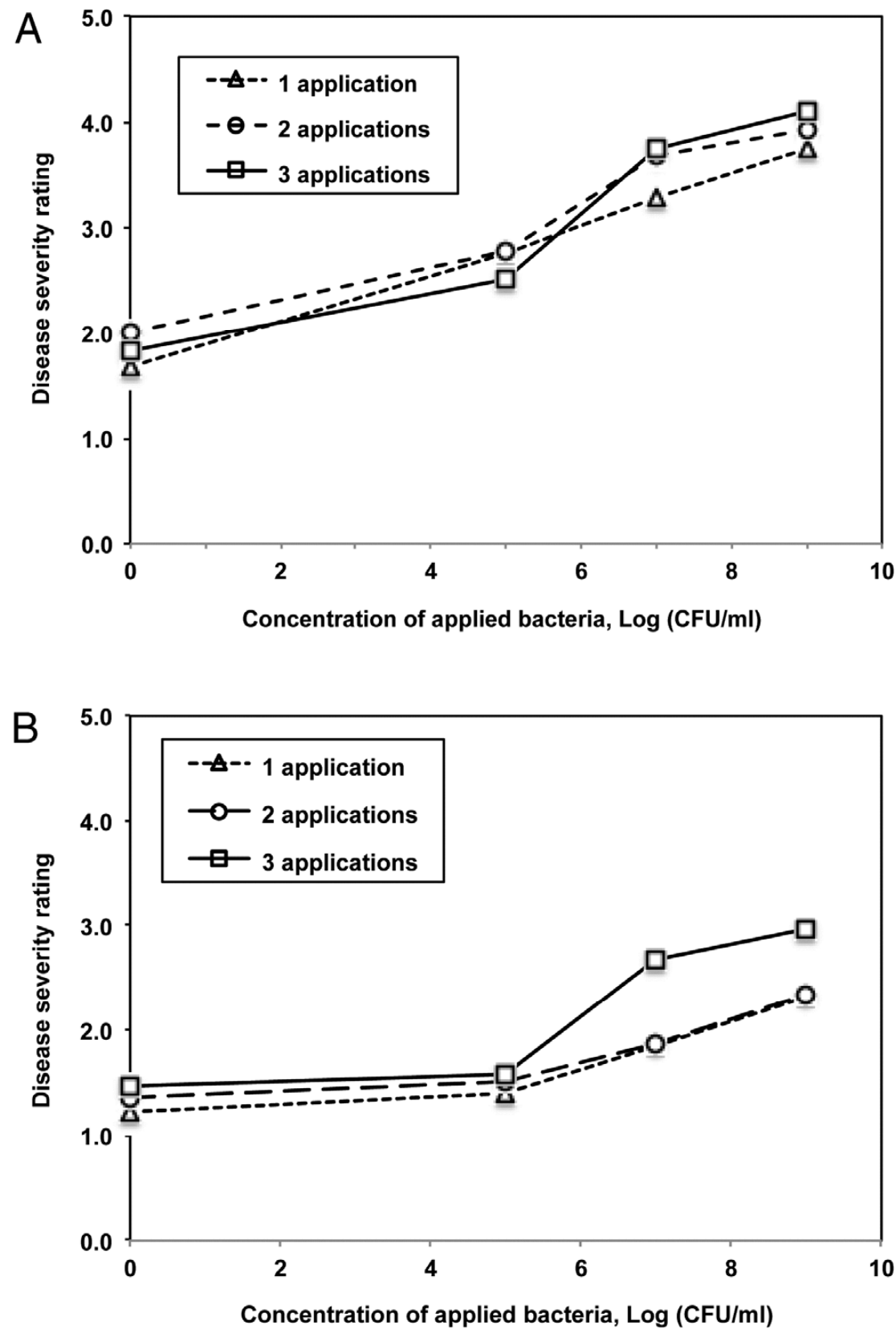

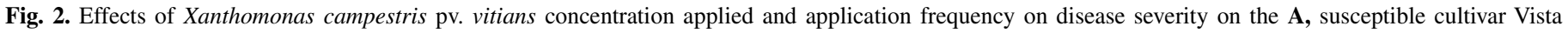

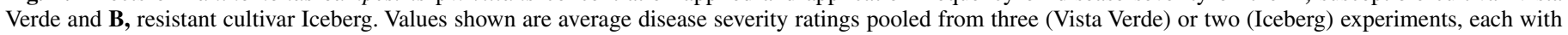

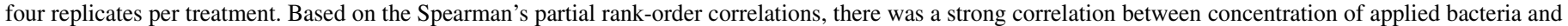

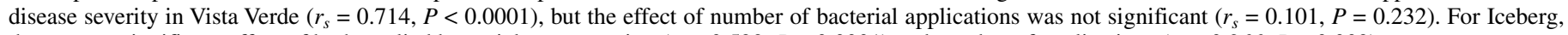
there was a significant effect of both applied bacterial concentration $\left(r_{s}=0.592, P<0.0001\right)$ and number of applications $\left(r_{s}=0.266, P=0.009\right)$. 
lettuce leaves sampled 3 weeks after inoculation did not significantly differ from those sampled 4.5 or 6 weeks after inoculation in experiment 1 and 2, respectively.

With bacteria applied at low or high levels as foliar spray inoculations. Bacterial population levels as analyzed by the AUPC were significantly lower in Little Gem than in Vista Verde $(P=$ 0.0406 , Tukey's HSD) or Sniper ( $P=0.0121$, Tukey's HSD) in experiments in which leaves of plants were spray-inoculated with low levels $\left(10^{4} \mathrm{CFU} / \mathrm{ml}\right)$ of $X$. campestris pv. vitians (Fig. 4A). Population levels on other cultivars were intermediate. Inoculation with suspensions containing high levels $\left(10^{9} \mathrm{CFU} / \mathrm{ml}\right)$ of $X$. campestris pv. vitians resulted in more pronounced differences among cultivars: Vista Verde, Sniper, and Salinas 88 had significantly higher AUPC values than those of Little Gem and Batavia Reine des Glaces, and Little Gem AUPC levels were also significantly lower than those of Clemente ( $P<0.05$, Tukey's HSD; Fig. 4B). These differences are likely due to the changes that are evident after 14 or 15 days. At both inoculum levels, significant differences were detected at 14 or 15 days and later (data not shown).

Population dynamics of $X$. campestris pv. vitians and plant reaction to infiltration of the pathogen into lettuce leaf tissue. Population levels of $X$. campestris pv. vitians strain BS2885 increased five- to tenfold within $24 \mathrm{~h}$ of the bacteria being infiltrated into the intercellular spaces of lettuce leaves regardless of cultivar (Fig. 5). Bacterial population levels in susceptible hosts (Vista Verde, Salinas 88, and Clemente) continued to increase for $72 \mathrm{~h}$ (3 days), but minimal further increases in population levels were detected during the remainder of the experiments. The maximum mean population levels reached for the susceptible cultivars ranged from 7.8 to $8.3 \mathrm{Log}\left(\mathrm{CFU} / \mathrm{cm}^{2}\right)$. By $72 \mathrm{hpi}$, the mean population levels in tissue of the resistant cultivar Little Gem were significantly lower than the levels in tissue of susceptible cultivars $(P=0.0001$ to 0.0003 , Tukey's HSD). In Little Gem, localized cell death at the injection site was detected microscopically at $24 \mathrm{hpi}$ and was clearly visible to the naked eye by $48 \mathrm{hpi}$. All other infiltrations, including those in the resistant cultivar Batavia Reine des Glaces, resulted in compatible interactions for which lesions became visible and cell death was detected at or after 48 and 72 hpi, respectively.

Bacterial population levels in Batavia Reine des Glaces were numerically intermediate between the lower levels of the pathogen in the resistant cultivar Little Gem and the higher levels reached by the pathogen in the susceptible cultivars in both experiments. The AUPC for Batavia Reine des Glaces was sig- nificantly greater $(P=0.005)$ than that of Little Gem and significantly less than those of the susceptible cultivars $(P=0.002$ to 0.016).

\section{DISCUSSION}

The progression of foliar bacterial plant diseases, including bacterial leaf spot in lettuce, in production fields is predicated on a succession of factors. First, pathogens (in this case X. campestris pv. vitians) are deposited on plant leaf surfaces by a number of different means $(7,33)$. Once deposited, pathogens may survive as epiphytes before colonization of natural openings or wounds in the plant tissue $(3,4,23,33)$. Internal colonization initiates direct interaction between the bacteria and plant cells $(33,44)$. We hypothesized that the lettuce genotype on which pathogenic bacteria alight would influence colonization (both phyllosphere and internal) and disease. The research presented here used lettuce cultivars well-characterized for their resistance or susceptibility to $X$. campestris pv. vitians to test this hypothesis. The research (i) documented the hypersensitive response in Little Gem in response to $X$. campestris pv. vitians, (ii) established that the relationship between bacterial population levels and disease severity was influenced by lettuce genotype, and (iii) demonstrated that overall colonization and internal population dynamics of $X$. campestris pv. vitians differed among cultivars. Thus, the epidemiology of bacterial leaf spot on lettuce is dependent on the host to which $X$. campestris pv. vitians immigrates.

In California field and greenhouse experiments, Little Gem has been repeatedly shown to be the most resistant commercially available cultivar (9). Of the three resistant cultivars included in these studies, only Little Gem demonstrated complete resistance and expressed the HR in response to infiltration of $X$. campestris pv. vitians into leaf tissue. Microscopic data and visual observations of plants inoculated by infiltration confirmed the development of the HR in Little Gem but not in Batavia Reine des Glaces, Iceberg (unpublished data), or the susceptible cultivars evaluated. For Little Gem, localized cell death at hydathodes was observed when the pathogen was spray-inoculated in other experiments. This represents the first demonstration of an HR induced by $X$. campestris pv. vitians in Lactuca sativa.

Cultivars Batavia Reine des Glaces and Iceberg, although resistant, did not exhibit the HR after infiltration with $X$. campestris pv. vitians (data not shown for Iceberg). In contrast to Little Gem, these cultivars exhibit partial resistance to all strains

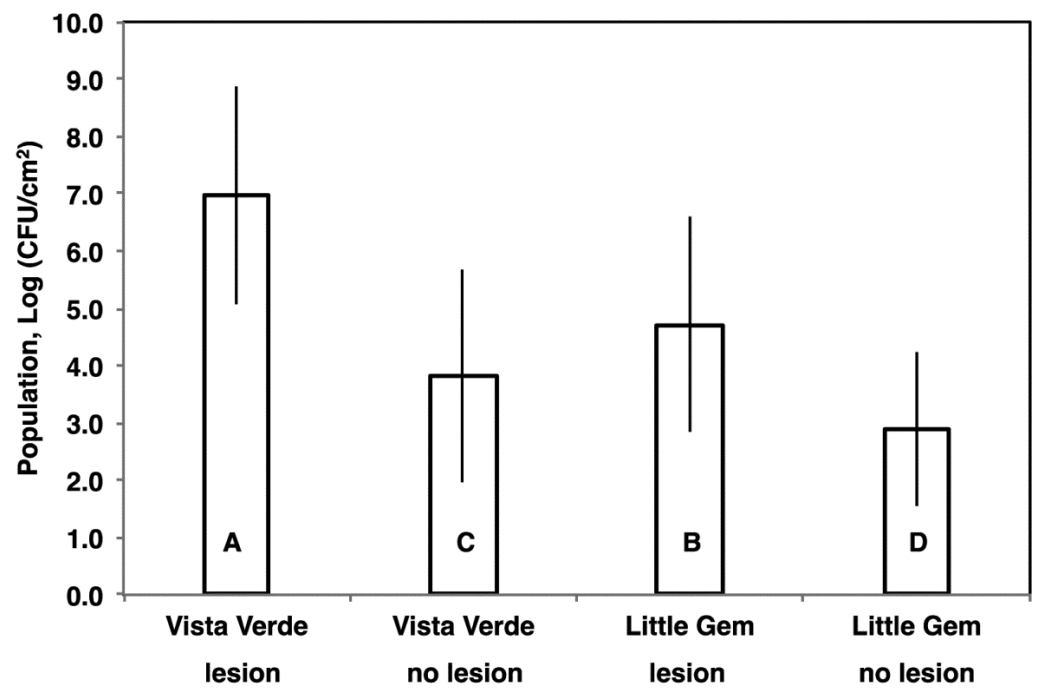

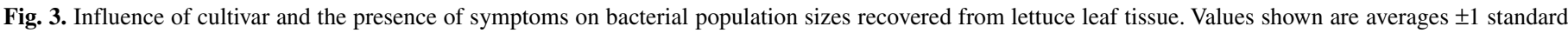

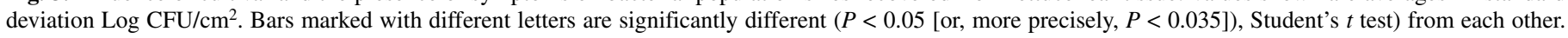
Little Gem and Vista Verde are resistant and susceptible cultivars, respectively. 
of $X$. campestris pv. vitians tested to date (9; unpublished data). In these cultivars, disease progressed from infiltration sites in a fashion typical of a compatible host-pathogen interaction. Additionally, internal colonization of lettuce leaf tissue by $X$. campestris pv. vitians differed among resistant cultivars. Between 24 and $72 \mathrm{hpi}$, the population levels of $X$. campestris pv. vitians in Little Gem tissue did not change or increased less than 1 Log $\mathrm{CFU} / \mathrm{cm}^{2}$. In contrast, population levels in susceptible cultivars and in the resistant cultivar Batavia Reine des Glaces increased approximately $3 \mathrm{Log} \mathrm{CFU} / \mathrm{cm}^{2}$ during this same time period. Overall, this resulted in significantly lower population levels in Little Gem than in the other cultivars. Similar results were observed when plants were spray-inoculated. However, in experiments for which the pathogen was spray-inoculated, the disease severity was significantly lower in all of the resistant cultivars, not just in Little Gem, compared with that in the susceptible cultivars (9). These data indicate that the mechanisms for resistance conferred by Batavia Reine des Glaces and Iceberg were different than that of Little Gem and were not mediated by the HR. Nothing is known about the inheritance of resistance in Iceberg and Batavia Reine des Glaces, although resistance in progeny from crosses with Batavia Reine des Glaces appear to be quantitatively distributed (18).

Susceptible cultivars also exhibited compatible interactions. No plant cell death was detected in the first $48 \mathrm{hpi}$, but disease developed at the site of infiltration after 7 days. At infiltration sites, the pathogen population levels in the susceptible cultivars Vista Verde and Salinas 88 increased from 6.0 to $8.5 \mathrm{Log}$ $\mathrm{CFU} / \mathrm{cm}^{2}$. The population dynamics described here for susceptible cultivars are very similar to data from previous work that

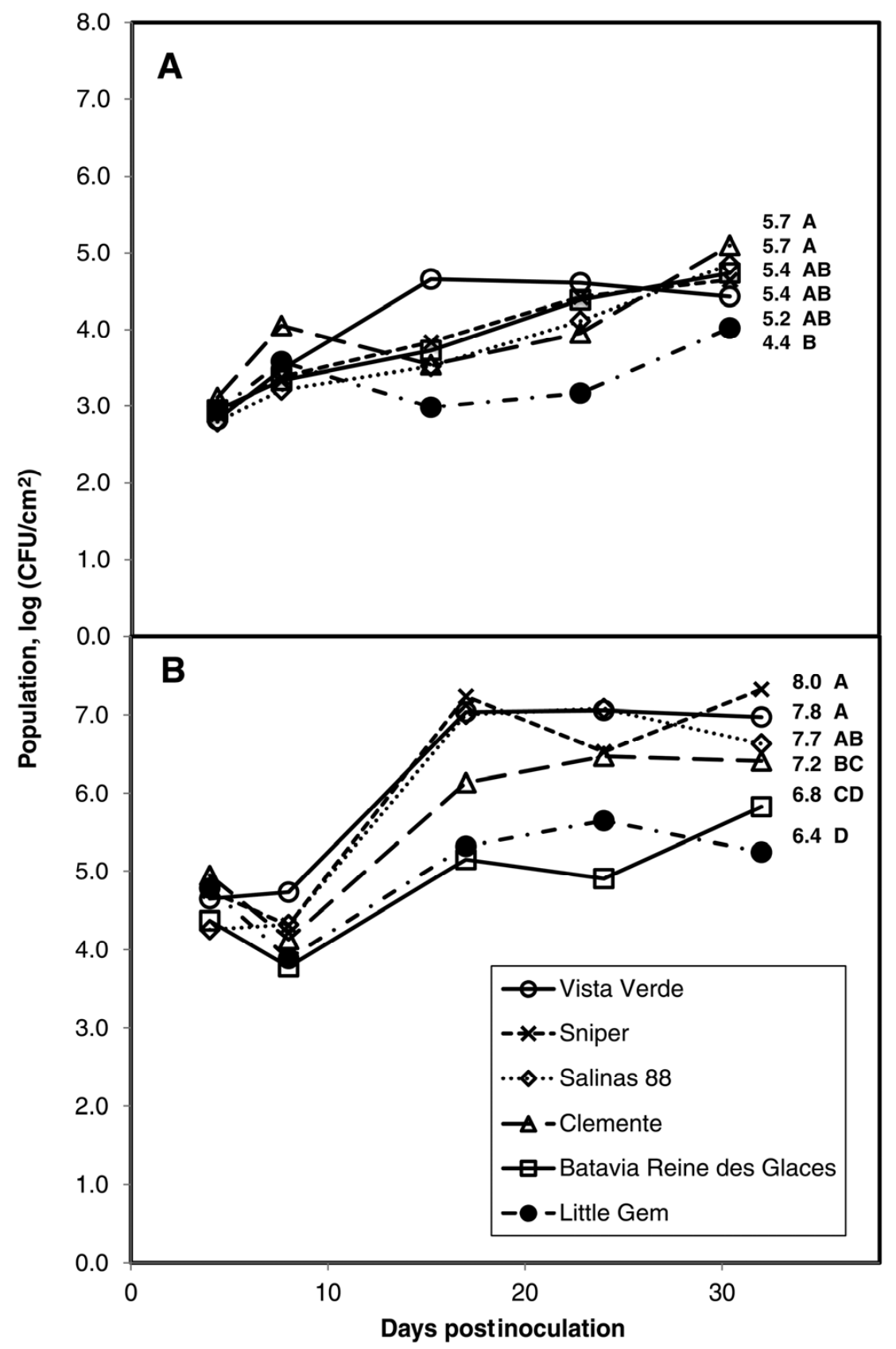

Fig. 4. Population dynamics of Xanthomonas campestris pv. vitians on six lettuce cultivars. Bacterial populations were measured for 4 to 32 or 4 to 28 days postinoculation with A, low or B, high levels, respectively, of Xanthomonas campestris pv. vitians inoculum on resistant (Little Gem, Batavia Reine des Glaces) and susceptible (Vista Verde, Sniper, Clemente, Salinas 88) cultivars. Values shown in each graph are averages from two independent experiments, each with six replicates per treatment. Area under the population curve (AUPC) values were calculated for each treatment and are shown at the endpoints of the lines. Different letters associated with these values indicate significant differences in the AUPC values $(P<0.05$, Tukey's HSD test). 
described population dynamics of $X$. campestris pv. vitians infiltrated into the susceptible cultivar Valmaine, in which the pathogen increased from 3.4 to over $8.0 \mathrm{Log} \mathrm{CFU} / \mathrm{cm}^{2}$ before disease development; likewise, electrolyte leakage was not detected during the early stages of infection, indicating a compatible interaction (32). In our replicated greenhouse studies, cultivar Valmaine was as susceptible to $X$. campestris pv. vitians BS0347 as was Vista Verde, and infiltration with the pathogen resulted in a compatible interaction ( 9 ; unpublished data).

In addition to the first demonstration of the HR in lettuce, this research represents the first demonstration of the differences in population dynamics of $X$. campestris pv. vitians on different lettuce genotypes. In these experiments, rates of multiplication and maximum bacterial cell densities were greater in the susceptible than in the resistant cultivars, and the population dynamics varied among resistant cultivars, which presumably had different mechanisms of resistance. Previously published research concentrated on susceptible cultivars and plants other than lettuce $(1,32,35,40)$; thus no information was available about differences in pathogen epidemiology in compatible and incompatible interactions with this pathosystem. Klement et al. (22) hypothesized that the rate of multiplication of bacteria in incompatible interactions was the same as that in compatible interactions but reached a lower stationary phase in planta. Stall and Cook (39) reported that the HR in pepper in response to Xanthomonas vesicatoria corresponded to a significantly lower population level compared with that in compatible interactions, seemingly confirming the Klement et al. (22) findings. The data presented here indicate that both population growth rate and final population sizes are smaller in the incompatible interaction in Little Gem than in compatible interactions in other lettuce cultivars.

Understanding the differences in population dynamics of a pathogen on various cultivars is important because differences in population levels translate to differences in disease incidence and/or severity. Our results indicate that resistant and susceptible cultivars respond differently to increasing populations of the pathogen. In susceptible cultivars, the increase in disease with increasing inoculum concentration was significantly more pronounced than in resistant cultivars. Lesion development in Little
Gem, in particular, did not increase at the same rate as in the susceptible cultivars in response to higher inoculum levels. Previous research showed that the infectivity titration endpoints for susceptible lettuce cultivars were $10^{3}$ to $10^{4} \mathrm{CFU} / \mathrm{ml}$ of inoculum sprayed onto plants in greenhouse experiments (32) and that susceptible cultivars could harbor more than $10^{5} \mathrm{CFU} / \mathrm{g}$ on asymptomatic tissue in field experiments (41). Our experiments confirmed the results of Robinson et al. (32): little to no disease was observed on susceptible cultivars inoculated with $10^{3} \mathrm{CFU} / \mathrm{ml}$. The current research extended these findings by also demonstrating that lesions were detected on both susceptible and resistant plants inoculated with $10^{5} \mathrm{CFU} / \mathrm{ml}$ and that, at this concentration, differences in disease severity among cultivars began to become apparent. Therefore resistance is most clearly detected when the plants are inoculated with high levels of the pathogen. This information has been used to improve screening methods to identify resistance.

A single dominant gene is responsible for conferring resistance in Little Gem, Pavane, and La Brillante to the $X$. campestris pv. vitians strains used in these experiments (21). However, X. campestris pv. vitians strains are heterogeneous. For example, it was previously demonstrated that $X$. campestris pv. vitians strains belong to two different species, $X$. hortorum and $X$. axonopodis (45). The strains used in the experiments reported in this manuscript belong to the $X$. hortorum group designated as group B by Sahin and Miller (36), one of five multilocus sequence types identified among $X$. hortorum strains causing bacterial leaf spot on lettuce (C. T. Bull and R. J. Hayes, unpublished data). It is not known whether additional differences in the epidemiology of the pathogen will be attributable to different avirulence genes present in these pathogens.

This manuscript provides a framework for understanding differences in population dynamics of $X$. campestris pv. vitians based on knowledge of the genetics of resistance to bacterial leaf spot in lettuce and allows us to put previously published research into this framework. This work begins to tease apart the interactions between $X$. campestris pv. vitians and host genotypes that determine the epidemiology of the pathogen. Our next goal is to examine the role of pathogen diversity in these interactions.

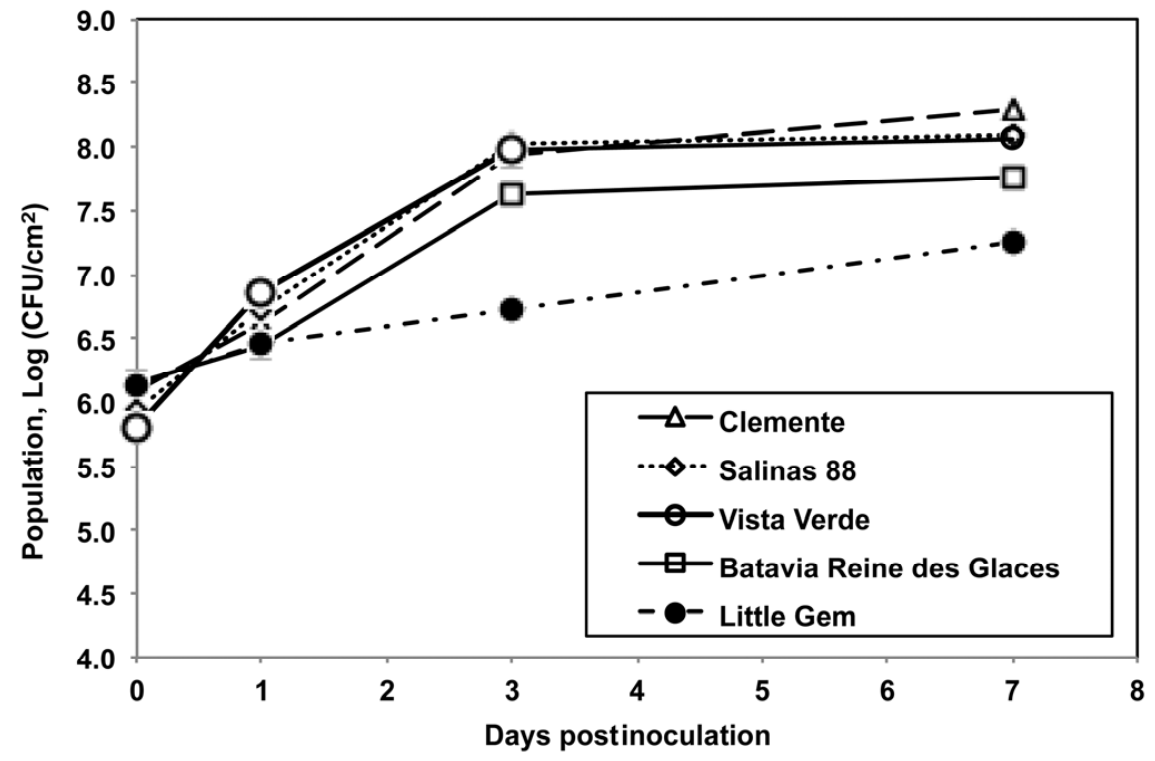

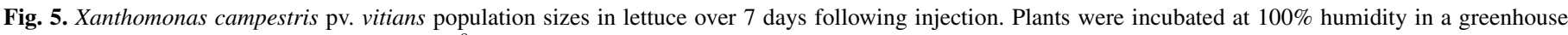

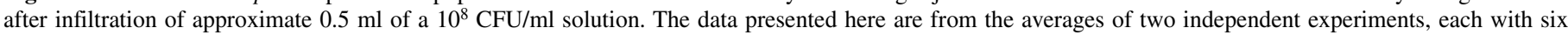

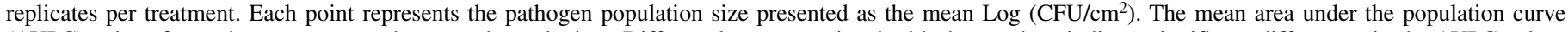

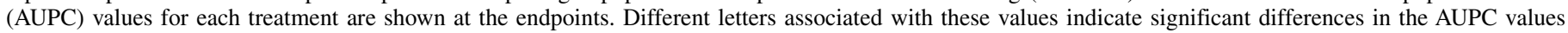

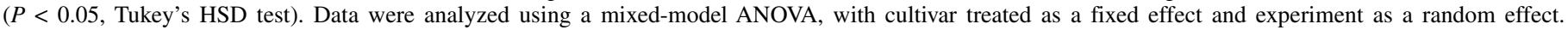

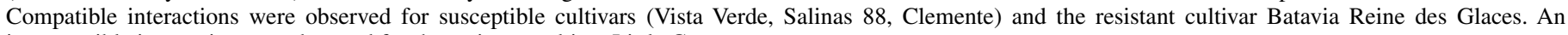
incompatible interaction was observed for the resistant cultivar Little Gem. 


\section{ACKNOWLEDGMENTS}

This research was supported by the California Leafy Greens Research Program and the California Department of Food and Agriculture. Partial funding for work by S. Gebben was provided by an NSF Science Talent Expansion Project (STEP) grant, No. 0525444, Hartnell College, Salinas, CA. Special thanks to Isaiah Martinez, Estefania Palacios, Andrew Roberts, Noemi Gomez, Ben Longcor, Ana Ibarra, Robert Lomeli, Bert Robinson, Jose Orozco, David Milligan, and Sharon Benzen for assistance with experiments. The mention of a trade name, proprietary product, or vendor does not constitute an endorsement, guarantee, or warranty by the U.S. Department of Agriculture and does not imply its approval or the exclusion of these or other products that may be suitable.

\section{LITERATURE CITED}

1. Al-Saleh, M. A., Ibrahim, Y. E., Abo-Elyousr, K. A. M., and Alibrahim, J. S. 2011. Population dynamics of Xanthomonas campestris pv. vitians on different plant species and management of bacterial leaf spot of lettuce under greenhouse conditions. Crop Protect. 30:883-887.

2. Barak, J. D., Koike, S. T., and Gilbertson, R. L. 2001. The role of crop debris and weeds in the epidemiology of bacterial leaf spot of lettuce in California. Plant Dis. 85:169-178.

3. Beattie, G. A., and Lindow, S. E. 1995. The secret life of foliar bacterial pathogens on leaves. Annu. Rev. Phytopathol. 33:145-172.

4. Beattie, G. A., and Lindow, S. E. 1999. Bacterial colonization of leaves: A spectrum of strategies. Phytopathology 89:353-359.

5. Boesewinkel, H. J. 1977. A new disease of lettuce. N.Z. J. Agric. Res. 2:54-55.

6. Bradbury, J. F. 1986. Guide to Plant Pathogenic Bacteria. CAB International, Slough, UK.

7. Bulgarelli, D., Schlaeppi, K., Spaepen, S., Ver Loren van Themaat, E., and Schulze-Lefert, P. 2013. Structure and functions of the bacterial microbiota of plants. Annu. Rev. Plant Biol. 64:807-838.

8. Bull, C. T., and Koike, S. T. 2005. Evaluating the efficacy of commercial products for management of bacterial leaf spot on lettuce. Plant Health Prog. doi:10.1094/PHP-2005-1121-01-RS

9. Bull, C. T., Goldman, P. H., Hayes, R., Madden, L. V., Koike, S. T., and Ryder, E. 2007. Genetic diversity of lettuce for resistance to bacterial leaf spot caused by Xanthomonas campestris pv. vitians. Plant Health Prog. doi:10.1094/PHP-2007-0917-02-RS

10. Bull, C. T., Trent, M., and Hayes, R. J. 2013. Internal colonization of lettuce leaves by Xanthomonas campestris pv. vitians is influenced by lettuce cultivar. (Abstr.) Phytopathology 103:S2.21.

11. Carisse, O., Ouimet, A., and Toussaint, V. 2000. Evaluation of the effect of seed treatments, bactericides, and cultivars on bacterial leaf spot of lettuce caused by Xanthomonas campestris pv. vitians. Plant Dis. 84:295-299.

12. Daboin, C., and Tortolero, O. 1993. Bacterial leaf spot of lettuce in some fields of the Venezuelan Andes. Fitopatol. Venezolana 6:8-10.

13. Davis, R. M., Subbarao, K. V., Raid, R. N., and Kurtz, E. A. 1997. Compendium of Lettuce Diseases. APS Press, St. Paul, MN.

14. Gebben, S. J., Hayes, R., and Bull, C. T. 2011. Lettuce cultivar influences Xanthomonas campestris pv. vitians population levels. (Abstr.) Phytopathology 101:S59.

15. Goldman, P. H., Koike, S. T., Ryder, E., and Bull, C. T. 2003. Influence of bacterial populations on leaf spot development in resistant and susceptible lettuce cultivars. (Abstr.) Phytopathology 93:S29.

16. Harrison, D. E. 1963. Leaf spot and dry rot of lettuce caused by Xanthomonas vitians (Brown) Dowson. Aust. J. Agric. Res. 14:778-784.

17. Hayes, R. J., Ryder, E. J., and Bull, C. T. 2008. Release of Iceberg Lettuce Germplasm with Resistance to Bacterial Leaf Spot Caused by Xanthomonas campestris pv. vitians. U.S. Dept. Agric., Agric. Res. Serv., Beltsville, MD.

18. Hayes, R. J., Trent, M., and Bull, C. T. 2013. A single gene confers resistance to bacterial leaf spot in the lettuce cultivar La Brillante. HortScience 48:S188.

19. Hayes, R. J., Trent, M., Mou, B., Simko, I., and Bull, C. T. 2013. Notice of release of baby leaf romaine breeding lines of lettuce with resistance to bacterial leaf spot caused by Xanthomonas campestris pv. vitians. Docket 0051.13. U.S. Dept. Agric., Agric. Res. Serv., Beltsville, MD.

20. Hayes, R. J., Trent, M., Mou, B., Simko, I., Gebben, S. J., and Bull, C. T. 2014. Baby leaf lettuce germplasm enhancement: Developing diverse populations with resistance to bacterial leaf spot caused by Xanthomonas campestris pv. vitians. HortScience 49:18-24.

21. Hayes, R. J., Trent, M. A., Truco, M. J., Michelmore, R. W., and Bull, C. T. The inheritance of resistance to bacterial leaf spot of lettuce caused by Xanthomonas campestris pv. vitians in three lettuce cultivars. Hort. Res. (In Press).
22. Klement, Z., Farkas, G. L., and Lovrekovich, L. 1964. Hypersensitive reaction induced by phytopathogenic bacteria in the tobacco leaf. Phytopathology 54:474-477.

23. Lindow, S. E., and Brandl, M. T. 2003. Microbiology of the phyllosphere. Appl. Environ. Microbiol. 69:1875-1883.

24. Lipp, R. L., Alvarez, A. M., Benedict, A. A., and Berestecky, J. 1992. Use of monoclonal antibodies and pathogenicity tests to characterize strains of Xanthomonas campestris pv. dieffenbachiae from aroids. Phytopathology 82:677-682.

25. Lu, H., Hu, J., and Kwon, S. J. 2014. Association analysis of bacterial leaf spot resistance and SNP markers derived from expressed sequence tags (ESTs) in lettuce (Lactuca sativa L.). Mol. Breed. doi:10.1007/s11032014-0092-5

26. Madden, L. V., Hughes, G., and Bosh, F. V. D. 2007. The Study of Plant Disease Epidemics. American Phytopathological Society, St. Paul, MN

27. Maisonneuve, B., Chassagne, C., Gautheron, E., Glaux, C., and Morris, C. 2007. Screening of genetic resources for resistance to Xanthomonas axonopodis pv. vitians. Page 14 in: EUCARPIA Leafy Vegetables 2007 Conference Abstracts. Presented at Eucarpia Leafy Vegetables 2007, Warwick, UK. http://prodinra.inra.fr/record/24356

28. Myung, I. S., Moon, S. Y., Jeong, I. H., Lee, S. W., Lee, Y. H., and Shim, H. S. 2010. Bacterial leaf spot of iceberg lettuce caused by Xanthomonas campestris pv. vitians type B, a new disease in South Korea. Plant Dis. 94:790.

29. Ohata, K., Serizawa, S., Azegami, K., and Shirata, A. 1982. Possibility of seed transmission of Xanthomonas campestris pv. vitians, the pathogen of bacterial spot of lettuce. Bull. Nat. Inst. Agric. Sci. 36:81-88.

30. Pennisi, A. M., and Pane, A. 1990. Gravi epidemie di Xanthomonas campestris pv. vitians (brown) Dye su lattuga in Sicilia. Inf. Fitopatol. 40:56-58.

31. Pernezny, K., Raid, R. N., Stall, R. E., Hodge, N. C., and Collins, J. 1995. An outbreak of bacterial spot of lettuce in Florida caused by Xanthomonas campestris pv. vitians. Plant Dis. 79:359-360.

32. Robinson, P. E., Jones, J. B., and Pernezny, K. 2006. Bacterial leaf spot of lettuce: Relationship of temperature to infection and potential host range of Xanthomonas campestris pv. vitians. Plant Dis. 90:465-470.

33. Ryan, R. P., Vorölter, F.-J., Potnis, N., Jones, J. B., van Sluys, M.-A., Bogdanove, A. J., and Dow, J. M. 2011. Pathogenomics of Xanthomonas: Understanding bacterium-plant interactions. Nature Rev. 9:344-355.

34. Sahın, F. 2000. First report of bacterial spot of lettuce caused by Xanthomonas campestris pv. vitians in Turkey. Plant Dis. 84:490.

35. Sahin, F., and Miller, S. A. 1997. Identification of the bacterial leaf spot pathogen of lettuce, Xanthomonas campestris pv. vitians, in Ohio, and assessment of cultivar resistance and seed treatment. Plant Dis. 81:1443-1446.

36. Sahin, F., Abbasi, P. A., Lewis Ivey, M. L., Zhang, J., and Miller, S. A. 2003. Diversity among strains of Xanthomonas campestris pv. vitians from lettuce. Phytopathology 93:64-70.

37. Schroth, M. N., Thompson, J. P., Bardin, R., and Greathead, A. 1964. Bacterial spot of lettuce. Calif. Agric. 18:2-3.

38. Shah, D. A., and Madden, L. V. 2004. Nonparametric analysis of ordinal data in designed factorial experiments. Phytopathology 94:33-43.

39. Stall, R. E., and Cook, A. A. 1966. Multiplication of Xanthomonas vesicatoria and lesion development in resistant and susceptible pepper. Phytopathology 56:1152-1154.

40. Toussaint, V. 1999. Bacterial leaf spot, a new disease of lettuce in Québec caused by Xanthomonas campestris pv. vitians. Phytoprotection 80:121-125.

41. Toussaint, V., Benoit, D. L., and Carisse, O. 2012. Potential of weed species to serve as a reservoir for Xanthomonas campestris pv. vitians, the causal agent of bacterial leaf spot of lettuce. Crop Protect. 41:64-70.

42. Tsuchiya, Y., Ohata, K., Azegami, K., and Matsuzaki, M. 1981. Pathogenicity of Xanthomonas campestris pv. vitians to various crops and weeds. Nogyo Gijutsu Ken-Kyusho Hokoku-Bull. Natal Inst. Agric. Sci. Ser. 35:57-77.

43. Umesh, K. C., Koike, S. T., and Gilbertson, R. L. 1996. Association of Xanthomonas campestris pv. vitians with lettuce seed. (Abstr.) Phytopathology 86:S3.

44. Underwood, W., Melotto, M., and He, S. Y. 2007. Role of plant stomata in bacterial invasion. Cell. Microbiol. 9:1621-1629.

45. Vauterin, L., Hoste, B., Kersters, K., and Swings, J. 1995. Reclassification of Xanthomonas. Int. J. Syst. Bacteriol. 45:472-489.

46. Wallıs, F. M., and Joubert, J. J. 1972. Bacterial leafspot of lettuce in Natal. Phytolactica 4:137-138.

47. Weller, D. M., and Saettler, A. W. 1978. Rifampin-resistant Xanthomonas phaseoli var. fuscans and Xanthomonas phaseoli: Tools for field study of bean blight bacteria. Phytopathology 68:778-781.

48. Zoina, A., and Volpe, E. 1994. Epidemiological aspects of lettuce bacterial spot induced by Xanthomonas campestris pv. vitians. Pages 797-802 in: Plant-Pathogenic Bacteria. M. Lemattre, S. Freigoun, K. Rudolph, and J. G. Swings, eds. INRA Colloquia, Versailles, France. 